\title{
НАКОПЛЕНИЕ ТЯЖЕЛЫХ МЕТАЛЛОВ (ТМ) РЯСКОЙ МАЛОЙ (LEMNA MINOR) В УСЛОВИЯХ АНТРОПОГЕННОГО ЗАГРЯЗНЕНИЯ РЕКИ ХОДЦА
}

\section{ACCUMULATION OF HEAVY (HM) DUCKWEED (LEMNA MINOR) UNDER CONDITIONS OF ANTHROPOGENIC POLLUTION OF THE HODZA RIVER}

V. Zubkova

F. Arslanbekova

Z. Makakhaniuk

Summary. The possibility of testing the state of water and bottom sediments of the Hodza River based on the study of the chemical composition of Lemna minor is being considered. A high positive relationship was established between the HM content in duckweed and bottom sediments of the river, a high positive relationship between the iron content in water and duckweed. A contrasting technogenic phytogeochemical anomaly in iron was revealed, which can be defined as selective, characteristic of duckweed. The biological absorption coefficients for the duckweed / water system are several orders of magnitude higher in comparison with the duckweed / bottom sediment system. According to the total removal of elements by duckweed, they can be arranged in a row: $\mathrm{Fe}>\mathrm{Zn}>\mathrm{Cu}>\mathrm{Pb}>\mathrm{Cd}$, which completely coincides with the range of the content of these elements in plants.

Keywords: anthropogenic pollution, heavy metals, bottom sediments, concentration coefficient, biological absorption coefficient, phytogeochemical anomaly.

\author{
Зубкова Валентина Михайловна \\ Д.б.н., профессор, Российский государственный \\ сочиальный университет (Москва) \\ vmzubkova@yandex.ru \\ Арсланбекова Флура Файзирахмановна \\ К.б.н., Российский государственный социальный \\ университет (Москва) \\ arslanka_65@mail.ru \\ Макаханюк Жанна Сергеевна \\ Аспирант, Российский государственный \\ сочиальный университет (Москва) \\ Nanochka16@mail.ru
}

Аннотация. Рассматривается возможность тестирования состояния воды и донных отложений реки Ходца на основе изучения химического состава Lemna minor. Установлена высокая положительная связь между содержанием ТМ в ряске и донных отложениях реки, высокая положительная связь между содержанием железа в воде и ряске. Выявлена контрастная техногенная фитогеохимическая аномалия по железу, которую можно определить как селективную, характерную для ряски. Коэффициенты биологического поглощения для системы ряска/вода на несколько порядков выше в сравнении с системой ряска/донные отложения. По общему выносу элементов ряской их можно расположить в ряд: $\mathrm{Fe}>\mathrm{Zn}>\mathrm{Cu}>\mathrm{Pb}>\mathrm{Cd}$, что полностью совпадает с рядом содержания этих элементов в растениях.

Ключевые слова: антропогенное загрязнение, тяжелые металлы, донные отложения, коэффициент концентрации, коэффициент биологического поглощения, фитогеохимическая аномалия.
Б ольшая роль в формировании и восстановлении качества природных вод принадлежит высшим водным растениям $[17,10,5]$.

Воздействие на растения различных токсикантов, в том числе и тяжелых металлов, приводит к снижению устойчивости биоценозов.

В связи с этим изучение химического состава водных растений, являющихся мощным аккумулятором загрязнителей, позволит выявить наиболее контрастные техногенные биогеохимические аномалии, образующиеся при загрязнении воды и донных отложений и уровень концентрации загрязнителей, создающий потенциальный экологический риск.
Тяжелые металлы относят к числу наиболее опасных химических загрязняющих веществ поверхностных вод. Попадая в водотоки, они долгое время могут оставаться в экосистеме, претерпевая трансформационные изменения, аккумулируясь растениями и животными, вызывая необратимые изменения и нарушения жизненно важных функций у большинства организмов [19, 20].

Высшие водные растения (ВВР), накапливая элементы-загрязнители могут удерживать их практически в течение всего вегетационного периода, исключая из круговорота в водоеме до своего отмирания и разложения. При этом они играют существенную роль в очистке водоемов от поллютантов [16]. 
Водные растения реагируют на присутствие в воде тяжелых металлов быстро. Металлы вызывают ряд изменений - в морфологии, анатомии, физиологических и биохимических процессах клеток растений. Для оценки степени токсичности металлов обычно используют параметры выживаемости и скорости роста растений, прежде всего гидрофитов. При этом биохимические изменения являются первичными в этой цепочке и могут служить биомаркером воздействия тяжелых металлов на растения [1]. В этой связи многие водные растения можно использовать для биотестирования и биоиндикации загрязнения металлами, а растения, способные накапливать тяжелые металлы,- применять для биоремедации и в очистке сточных вод $[3,15]$.

ВВР оказывает разностороннее воздействие на динамику водных масс и донных отложений. Прежде всего, она оказывает механическое сопротивление движению воды и тем самым способствует осаждению взвешенных в воде веществ и их накоплению. Кроме того, растительность накапливает (сорбирует) различные вещества на листьях и стеблях, а также поглощает их в процессе обмена с внешней средой. Количество накапливаемых растительностью биогенных элементов, металлов и других загрязняющих веществ может исчисляться десятками и сотнями тысяч тонн [7].

Данная проблема становится особенно актуальной на территориях с разноплановым и многокомпонентным техногенным воздействием.

Целью наших исследований явилось определение аккумулирующей способности и роли ряски малой в миграциях ТМ на примере малой реки Ходца.

\section{Метолы}

Материалом для исследований послужили пробы воды, почвы и образцы прибрежно-водной растительности, отобранные в летний период (начало августа) 2020 г. в малой реке Ходца вблизи крупного промышленного центра г. Электросталь Московской области.

С учетом строения береговой линии нами было установлено три створа: в истоке (55.810586 с.ш., 38.480605 в.д.), в промежуточной точке (55.808665 с.ш., 38.507754 в.д.) и в устье (55.773356 с.ш., 38.637410 в.д.).

Содержание ТМ в образцах воды, донных отложений и растениях определено атомно-абсорбционным методом по методикам, представленным в природоохранных нормативных документах федерального уровня, в аккредитованных испытательных лабораториях МГУ имени М.В.Ломоносова, филиала Федерального бюджетного учреждения здравоохранения «Центр ги- гиены и эпидемиологии в Московской области» и «Центре сертификации и экологического мониторинга агрохимической службы “Московский”».

Для установления характера связи между содержанием загрязнителей в изучаемых компонентах проведен корреляционный анализ.

Для определения аккумуляции исследуемых тяжелых металлов использовали коэффициент концентрации (КК) или коэффициент биологического накопления (КБН), показывающий способность растений избирательно поглощать химические элементы. Его вычисляли как отношение содержания элемента в растении к содержанию в воде или донных отложениях.

\section{Результаты и обсужкение}

В результате проведенных исследований прибрежно-водной растительности, выявлено, что из-за неблагоприятных гидрохимических свойств воды Lemna minor является одним из двух видов растений (второй вид - Carex aquatilis), преобладающих в малой реке Ходца.

Представители семейства рясковые (Lemnaceae) перспективный экспериментальный объект для экотоксикологических исследований и биомониторинга в силу своей химической чувствительности. Ряска малая (Lemna minor), которой представлено это семейство в изучаемом водном объекте - однодольное покрытосеменное растение, неукорененный плейстофит, с упрощенным строением [14].

Она широко распространена в стоячих или с медленным течением водоёмах и довольно чувствительна к загрязнению ТМ [4].

Результаты наших исследований свидетельствуют о дифференциации в интенсивности накопления ТМ растениями Lemna minor, отобранными на разных участках реки Ходца (табл. 1). Так, содержание кадмия, свинца, цинка и меди в пространстве варьировало в 1,1-1,2 раза; железа - 7,8 раза.

В первую очередь к резкому обеднению фитоценоза реки высшей водной растительностью по нашим данным приводит содержание в воде железа. Постоянное превышение ПДК по этому элементу способствует накоплению его в растениях ряски до 5864 мг/кг сухой массы. В литературе встречаются единичные данные по такой высокой концентрации железа в водных растениях [6].

Нашими исследованиями установлено, что такое концентрирование осокой железа происходило 
Таблица 1. Содержание ТМ в воде, донных отложениях и Lemna minor

\begin{tabular}{|c|c|c|c|}
\hline Определяемый показатель & $\begin{array}{l}\text { Содержание ТМ в воде, } \\
\text { мг/дм }\end{array}$ & $\begin{array}{l}\text { Содержание ТМ в донных } \\
\text { отложениях, } \\
\text { мг/кг }\end{array}$ & $\begin{array}{l}\text { Содержание ТМ в Lemna } \\
\text { minor, мг/кг }\end{array}$ \\
\hline $\mathrm{Fe}$ & $\begin{array}{l}18,7 \pm 2,8 \\
0,522 \pm 0,157\end{array}$ & $\begin{array}{l}5159 \pm 361 \\
1374 \pm 96\end{array}$ & $\begin{array}{l}5864,32 \pm 879,65 \\
754,60 \pm 113,19 \\
\end{array}$ \\
\hline $\mathrm{Cd}$ & $\begin{array}{l}0,0005 \pm 0,0001 \\
0,0005 \pm 0,0001\end{array}$ & $\begin{array}{l}2,29 \pm 0,16 \\
0,45 \pm 0,03\end{array}$ & $\begin{array}{l}0,571 \pm 0,064 \\
0,464 \pm 0,054\end{array}$ \\
\hline $\mathrm{Pb}$ & $\begin{array}{l}0,02 \pm 0,006 \\
0,02 \pm 0,006\end{array}$ & $\begin{array}{l}6,28 \pm 0,44 \\
5,11 \pm 0,36\end{array}$ & $\begin{array}{l}0,539 \pm 0,051 \\
0,491 \pm 0,053\end{array}$ \\
\hline Zn & $\begin{array}{l}0,03 \pm 0,003 \\
0,01 \pm 0,001\end{array}$ & $\begin{array}{l}24,9 \pm 2,13 \\
33,8 \pm 4,01\end{array}$ & $\begin{array}{l}34,68 \pm 2,93 \\
41,75 \pm 3,18\end{array}$ \\
\hline $\mathrm{Cu}$ & $\begin{array}{l}0,02 \pm 0,002 \\
0,04 \pm 0,001\end{array}$ & $\begin{array}{l}6,73 \pm 0,44 \\
8,23 \pm 0,92\end{array}$ & $\begin{array}{l}8,76 \pm 1,41 \\
10,14 \pm 1,38\end{array}$ \\
\hline
\end{tabular}

*В числителе - исток; в знаменателе - промежуточная точка

Таблица 2. Содержание железа в воде, донных отложениях и береговом грунте реки Ходца в летнюю межень, среднее за 2018-2020 гг.

\begin{tabular}{|l|l|l|l|}
\hline Место взятия образца & Вода, мг/дм³ & Донные отложения, мг/кг & Береговой грунт, мг/кг \\
\hline Исток & 18,5 & $5159 \pm 1548$ & $902 \pm 271$ \\
\hline Среднее течение & 1,76 & $1374 \pm 412$ & $790 \pm 237$ \\
\hline Нижнее течение & 9,94 & $577+173$ & $2625 \pm 788$ \\
\hline
\end{tabular}

Таблица 3. Корреляционная зависимость содержания TM в Lemna minor, воде и донных отложениях

\begin{tabular}{|l|l|l|l|l|l|} 
Варианты & Железо & Кадмий & Свинец & Цинк & Медь \\
\hline Вода & $\mathrm{R}=0,66$ & - & - & $\mathrm{R}=-0,30$ & $\mathrm{R}=0,31$ \\
\hline Характер связи & высокая положительная & - & - & $\begin{array}{l}\text { средняя } \\
\text { отрицательная }\end{array}$ & $\begin{array}{l}\text { средняя } \\
\text { положительная }\end{array}$ \\
\hline ДО & $\mathrm{R}=0,66$ & $\mathrm{R}=0,64$ & $\mathrm{R}=0,62$ & $\mathrm{R}=0,65$ & $\mathrm{R}=0,63$ \\
\hline Характер связи & высокая положительная & \multicolumn{3}{l|}{} \\
\hline
\end{tabular}

на фоне превышения его допустимых норм в среднем за 3 года в воде в 5,9-33,1 раза (табл. 2).

Высокая накопительная способность L.minor по отношению к тяжельм металлам может свидетельствовать о зависимости процесса аккумуляции от степени контакта растения с водной средой. Е.М. Коробова указывает, что влаголюбие вида может играть большую роль в накоплении химических элементов, чем его систематическое положение [9].

Химический состав растений отражает элементный состав среды обитания, в связи с чем содержание изучаемых элементов в большей степени должно коррелировать с составом донных отложений.

Корреляционный анализ зависимости содержания ТМ в ряске от концентрации ТМ в воде и донных отложениях показал на высокую положительную связь кон- центрации всех изучаемых ТМ в растениях с их количеством в донных отложениях (табл. 3).

С содержанием ТМ в воде и ряской установлена высокая положительная связь только по железу.

Механизмы устойчивости ряски к избытку ТМ проявляются, очевидно, в способности накапливать высокие концентрации ТМ, при этом проявлять к ним толерантность; другие растения стремятся снизить их поступление путем максимального использования своих барьерных функций [11].

Расчет коэффициентов концентрирования (КК) ТМ по отношению к водной среде и донным отложениям, характеризующих степень толерантности растений и являющихся критериями при выборе биоиндикаторов, показал, что они определяются видом элемента и его концетрацией в среде (табл. 4). 
Таблица 4. Коэффициенты биоконцентрирования ТМ ряской малой, 2020 г

\begin{tabular}{|l|l|l|l|}
\hline \multirow{3}{*}{ Элемент } & \multicolumn{1}{|l|}{ По содержанию в воде } & По содержанию в донных отложениях \\
\hline \multirow{2}{*}{$\mathrm{Pb}$} & 1. & 1142 & 0,25 \\
\cline { 2 - 4 } & 2. & 928 & 1,03 \\
\hline \multirow{2}{*}{$\mathrm{Fe}$} & 1. & 27 & 0,09 \\
\hline \multirow{2}{*}{$Z \mathrm{n}$} & 2. & 25 & 0,10 \\
\hline \multirow{2}{*}{$\mathrm{Cu}$} & 1. & 314 & 1,14 \\
\cline { 2 - 4 } & 2. & 1446 & 0,55 \\
\hline
\end{tabular}

*1 - исток; 2 - Промежуточная точка.

Таблица 5. Продуктивность Lemna minor в реке Ходца в 2020 г., г/м²

\begin{tabular}{|l|l|l|l|l|l|}
\hline Место отбора проб & Число растений & Число щитков & $\begin{array}{l}\text { Число } \\
\text { щитков } \\
\text { с повреждениями }\end{array}$ & $\begin{array}{l}\text { \% щитков с по- } \\
\text { вреждениями }\end{array}$ & $\begin{array}{l}\text { Сухая масса, } \\
\text { г/м² }\end{array}$ \\
\hline Исток & $150 \pm 14$ & $160 \pm 13$ & $36 \pm$ & 22,5 & 42,2 \\
\hline $\begin{array}{l}\text { Промежуточная } \\
\text { ТОчка }\end{array}$ & $200 \pm 16$ & $750 \pm 54$ & - & Отсутствуют & 48,7 \\
\hline НСР 05 & & & & & 4,08 \\
\hline
\end{tabular}

Установленная зависимость коэффициентов биологического поглощения металлов в растениях от содержания соответствующих ТМ в воде и донных отложениях неоднозначна в пространстве.

Однозначным является лишь то, что тяжёлые металлы поглощаются активнее в системе ряска-вода, чем в системе ряска-донные отложения. Коэффициенты биологического поглощения для системы ряска/вода на несколько порядков выше по сравнении с системой ряска/донные отложения.

К настоящему времени опубликованы работы, посвященные оценке аккумулятивной способности различных видов ряски и их использованию для очистки сточных и рудничных вод от тяжелых металлов и других поллютантов $[2,13,18,21]$.

В соответствии с полученными данными ряску по отношению к воде можно отнести к сверконцентраторам. По отношению к донным отложениям ряска является аккумулятором кадмия, железа, цинка и меди. Поэтому в силу своей химической чувствительности Lemna minor - перспективный экспериментальный объект для экотоксикологических исследований и биомониторинга.

Ряску малую (Lemna minor) многие авторы считают оптимальным биоиндикатором, так как она реагирует на различные виды загрязнений. В связи с чем Lemna minor широко используется в фитоиндикации.

Кроме того, способность растений семейства рясковых к извлечению и накоплению значительный количеств металлов активно используется в технологии очистки стоков.

Одним из главных параметров при оценке загрязненности водоемов является их биологическая продуктивность. Все металлы связаны со степенью биопродуктивности следующим образом: негативное действие токсичных металлов, как правило, увеличивается с уменьшением биопродуктивности. Показатель биопродуктивности лежит в основе определения экологического риска. При этом показатель биопродуктивности водоема, используется как показатель его трофического уровня.

Нами оценена продуктивность ВВР в разных участках реки Ходца (табл. 5).

Сухая масса растений существенно различалась в зависимости от места отбора проб (табл. 5). Плотность

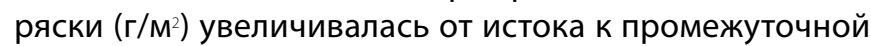
точке.

В нижнем течении растения ряски отсутствовали, что, очевидно связано как со скоростью движе- 
Таблица 6. Накопление TM Lemna minor, мг/м²

\begin{tabular}{|l|l|l|}
\hline Показатели & Исток & Промежуточная точка \\
\hline $\mathrm{Cd}$ & 0,025 & 0,023 \\
\hline $\mathrm{Pb}$ & 0,023 & 0,026 \\
\hline $\mathrm{Fe}$ & 247,47 & 36,75 \\
\hline $\mathrm{Zn}$ & 1,46 & 2,03 \\
\hline $\mathrm{Cu}$ & 0,370 & 0,494 \\
\hline
\end{tabular}

ния воды, так и с меньшим содержанием биогенов по сравнению с верхним течением. От верхней точки к промежуточной содержание практически всех загрязнителей уменьшалось. Кроме того, возрастало значение $\mathrm{pH}$.

По приведенным результатам можно рассчитать количество ТМ, вовлекаемых в биологический круговорот на определенный период времени (табл. 6).

Общее количество извлекаемых растениями загрязнителей изменялось в широких пределах в зависимости от вида растений и изучаемых элементов.

Биологический вынос элементов у Lemna minor

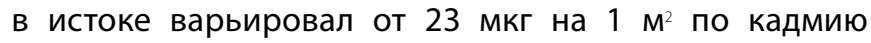
до 247470 мкг на 1 м² $^{2}$ по железу; в промежуточной точке по тем же элементам - от 23 до 36750 мкг. Таким образом, интервал колебаний в выносе кадмия и железа отмечен в 1598-10760 раз.

По общему выносу элементов во всех местах отбора проб их можно расположить в следующий убывающий ряд:

$\mathrm{Fe}>\mathrm{Zn}>\mathrm{Cu}>\mathrm{Pb}>\mathrm{Cd}$, то есть он полностью совпадает с рядом содержания этих элементов в растениях.
Однако ряска очень быстро размножается, давая огромные урожаи зеленой массы с единицы площади водоема. Она одинаково хорошо растет как в сухое, так и в дождливое лето. При регулярном удалении ее за сезон собирают для кормления рыбы до 80 т/га. По некоторым данным, суточный прирост ряски составляет 10-20\% от общей массы. Лучше делать сборы каждые 5-10 дней.

Высокая урожайность обусловливается тем, что ряска состоит из фотосинтезирующих и размножающихся клеток. Имея малые размеры и покрывая поверхность водоема, ряска поглощает почти всю физиологически полезную солнечную радиацию. Ряска усваивают не только минеральные вещества, но и интенсивно поглощает ТМ [12].

\section{Зак^ючение}

В связи с усиливающимся загрязнением природной среды многие токсичные вещества попадают в водотоки, где они аккумулируются в организмах гидробионтов, достигая значительных величин, что может привести их к гибели [8]. Только немногие виды, способные переносить сильное загрязнение среды обитания и высокие дозы загрязняющих веществ, приспосабливаются к антропогенному прессингу. В реке Ходца одним из таких видов растений является Lemna minor.

\section{ЛИТЕРАТУРА}

1. Акмуханова, Н.Р. Создание консорциума высших водных растений и микроводорослей для очистки сточных вод от ионов тяжелых металлов [Текст] / Н.Р. Акмуханова, Б.К. Заядан, А.К. Садвакасова [и др.] // Физиология растений, 2018. — том 65.— № 1. - С. 73-80.

2. Бардюкова, А.В. 0 возможности применения свободноплавающих гидрофитов водных экосистем Беларуси для очистки сточных вод от соединений металлов методом фиторемедиации [Текст] / А.В. Бардюкова, 0.В. Ковалёва // Вестник Приамурского государственного университета им. Шолом-Алейхема», 2019. — № 3(36). - C. 9-16.

3. Вайсман, Я.И. Использование водных растений для доочистки сточных вод [Текст] / Я.И. Вайсман, Л.В. Рудакова, Е.В. Калинина // Экология и промышленность России. - 2006. - № 11.—C. 9-11.

4. Горленко, В.М. Экология водных микроорганизмов [Текст] / В.М. Горленко, Г.А Дубинина, С.И. Кузнецов. — М.: Наука, 1977.— 289 с.

5. Дайнеко, Н.М. Накопление тяжелых металлов прибрежно-водной растительностью водоемов вблизи г. Жлобина Гомельской области Республики Беларусь [Текст] / Н.М. Дайнеко, С.Ф. Тимофеев, С.В. Жадько // Известия Томского политехнического университета. Инжиниринг георесурсов.2016. - Т. 327. — № 5. - C. 124-132.

6. Железнова, С.Н. Баланс железа в плотной культуре диатомовой водоросли Cylindrotheca closterium (Ehrenberg) Reimann \& J.C. Lewin [Teкст]: материалы международ, науч. конференции, посвящ. 125-летию Института физиологии растений им. К.А. Тимирязева РАН Москва. — M., 2015.- С. $238-241$. 
7. Казмирук В.Д. Накопление тяжелых металлов высшей водной растительностью различных биотопов устьевой области Волги [Текст]: материалы III Всероссийской конференции по водной токсикологии, посвящ. памяти Б.А. Флерова. - Борок, 2008. — С. 30-34.

8. Капитонова, O.A. Особенности аккумуляции тяжелых металлов ряской малой (Lemna minor L.) [Электронный ресурс].— Режим доступа: https:// cyberleninka.ru/article/n/osobennosti-akkumulyatsii-tyazhyolyh-metallov-ryaskoy-maloy-lemna-minor-I (дата обращения: 1.06.2021 г.).

9. Коробова, Е.М. Миграция меди кобальта и йода в ландшафтах Юго-Восточной Мещеры [Текст] / Е.М. Коробова // Эколого-геохимический анализ техногенного загрязнения. - М.: ИМГРЭ, 1991.— С. 3-17.

10. Красильникова, Н.С. Растения семейства Lemnaceаe как биоиндикаторы экологического состояния водных экосистем [Текст]: материалы Всероссийской научно-технической интернет конференции. - Орел: Орел Гту, 2009. - 220с.

11. Макаханюк, Ж.С. Миграция тяжелых металлов в системе береговой грунт — донные отложения — растения реки Ходца в период летней межени 2019 [Текст] / Ж.С. Макаханюк, В.М. Зубкова, Л.А. Розумная // Вестник АГТУ. Сер.: Рыбное хозяйство.— 2020.— № 2.— C. 67-74.

12. Моисеев, Н.Н. Живые корма [Текст]: учеб. пособие / Н.Н. Моисеев, С.В. Севастеев. - Новосибирск, 2016. - 115 с.

13. Никаноров, А.М. Биомониторинг металлов в пресноводных экосистемах [Текст] / А.М. Никаноров, А.В. Жулидов // Л.: Гидрометеоиздат, 1991.—312 с.

14. Цаценко, Л.В. Рясковые как модельный объект в биотестировании водной и почвенной среды [Текст] / Л.В. Цаценко, В.Г. Пасхалиди // Масличные культуры, 2018.- Вып. 4 (176).-С. 146-51.

15. Чачина, С.Б. Использование биотехнологических методов доочистки нефтесодержащих сточных вод промышленных предприятий [Электронный ресурс].— Режим доступа: https://applied-research.ru/ru/article/view?id=5741 (дата обращения: 31.05.2021).

16. Шашуловская, Е.А. 0 накоплении тяжелых металлов в высшей водной растительности Волгоградского водохранилища [Текст] / Е.А. Шашуловская // Поволжский экологический журнал, 2009.— № 4.- С. 357-360.

17. Шуйский, В.Ф. Биоиндикация качества водной среды, состояния пресноводных экосистем и их антропогенных изменений [Текст] / В.Ф. Шуйский, Т.В. Максимова, Д.С. Петров // Сб. научн. докл. VII междунар. конф. «Экология и развитие Северо-Запада России».— СПб.: Изд-во МАНЭБ, 2002 г.— $19 \mathrm{C}$.

18. Galczynska, M. Possibilities and limitations of using Lemna minor, Hydrocharis morsus-ranae and Ceratophyllum demersum in removing metals with contaminated water [Text] / M. Galczynska, N. Mankowska, J. Milke, M. Busko // Journal of Water and Land Development. — 2019. — No 40 (I-III). — P. 161173.

19. Ghazaryan, K. Copper phytoremediation potential of wild plant species growing in the mine polluted areas of Armenia [Text] / K. Ghazaryan // Environmental Pollution. - 2019. - T 249. - P. 491-501.

20. Guo, J. Bioassessment of heavy metal toxicity and enhancement of heavy metal removal by sulfate-reducing bacteria in the presence of zero valent iron [Text] / J. Guo, Y. Kang, Y. Feng// Journal of environmental management. - 2017. - T. 203. - P. 278-285.

21. Sasmaz, A. Removal of Cr, Ni, and $\mathrm{Co}_{\text {in }}$ the water of chromium mining areas by using Lemna gibba L. and Lemna minor L. [Text] / A. Sasmaz, I.M. Dogan, M. Sasmaz // Water and Environment Journal. — 2016. — No 30 (3-4). - P. 235-242.

(c) Зубкова Валентина Михайловна ( vmzubkova@yandex.ru),

Арсланбекова Флура Файзирахмановна ( arslanka_65@mail.ru ), Макаханюк Жанна Сергеевна ( Nanochka16@mail.ru ).

Журнал «Современная наука: актуальные проблемы теории и практики» 